\title{
Holmes Tremor With Perirolandic Demyelinating Lesions
}

\section{A Distinct Clinicoradiographic Syndrome}

Adrian Budhram, MD, Hugh D. Simpson, MBBS, PhD, James H. Bower, MD, Anhar Hassan, MBBCh, Brittani L. Conway, MD, and Eoin P. Flanagan, MBBCh

Neurology ${ }^{\circledR}$ 2021;96:231-232. doi:10.1212/WNL.0000000000011235

Figure Brain MRI in 2 Patients With Holmes Tremor and Perirolandic Demyelinating Lesions
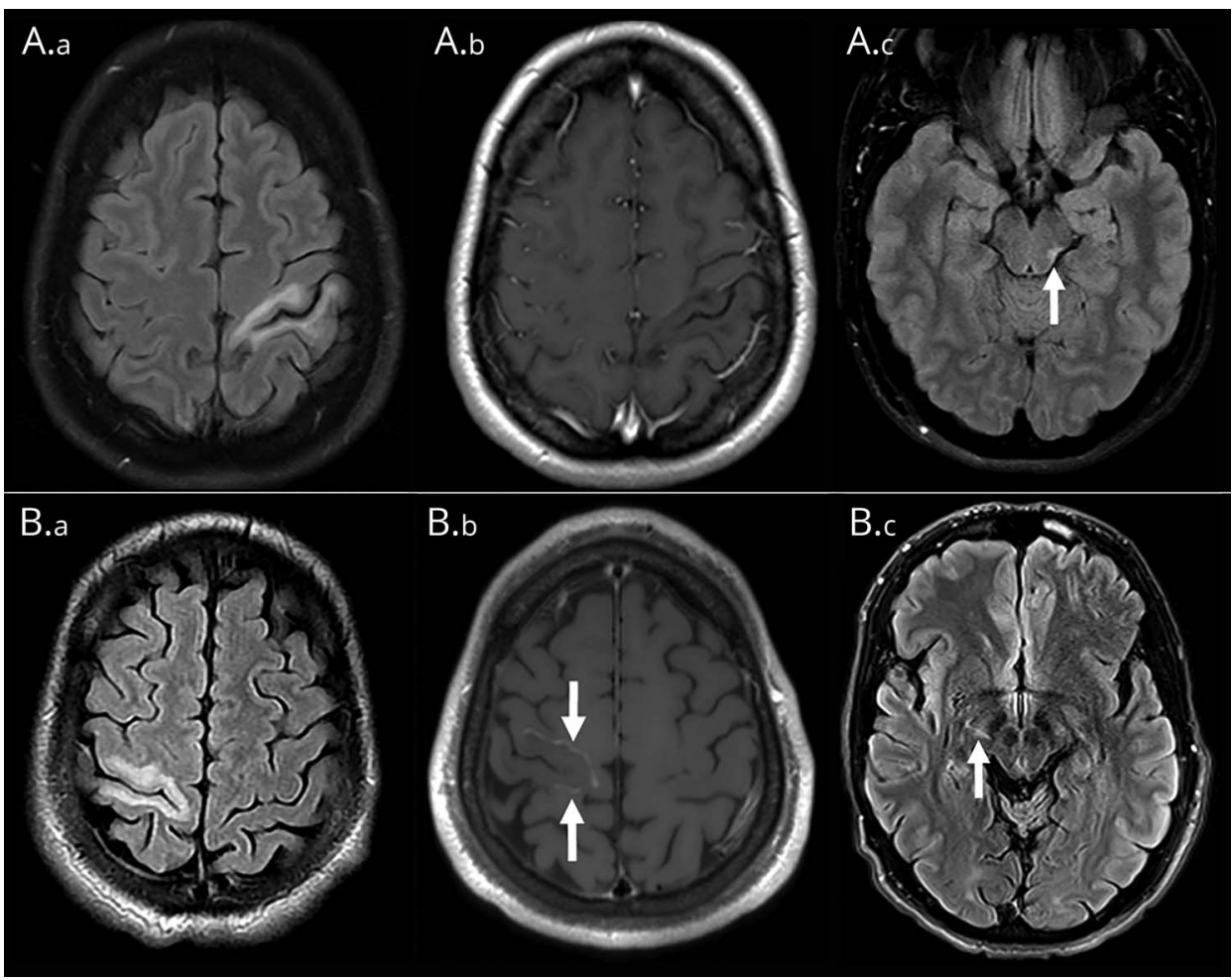

Both patients had persistent unilateral perirolandic T2-fluid-attenuated inversion recovery (FLAIR) hyperintense (A.a, B.a), T1-hypointense (A.b, B.b) lesions with transient gadolinium enhancement in patient B (B.b, arrows) Patient A also had a left posterolateral mesencephalic T2-FLAIR hyperintense lesion (A.C, arrow). Patient B developed linear right cerebral peduncle T2-FLAIR hyperintensity that was not observed on initial MRI 3 months after tremor onset, suggesting Wallerian degeneration (B.C, arrow).

Patients A (38-year-old woman) and B (30-year-old man) developed unilateral, slowly progressive $4-6 \mathrm{~Hz}$ tremor over months to years with rest, postural, and intentional components (videos 1 and 2 ), indicating Holmes tremor. ${ }^{1}$ Both had contralateral perirolandic lesions (figure). Patient $\mathrm{A}$ had a midbrain lesion (figure) and CSF-specific oligoclonal bands; patient $\mathrm{B}$ had enhancement, MRI suggesting Wallerian degeneration (figure), and transient low-titer MOG immunoglobulin G positivity of doubtful clinical

\section{Correspondence}

Eoin P. Flanagan

flanagan.eoin@mayo.edu
MORE ONLINE

- Videos

From the Departments of Neurology (A.B., H.D.S., J.H.B., A.H., B.L.C., E.P.F.) and Laboratory Medicine and Pathology (E.P.F.), Mayo Clinic, Rochester, MN; and Department of Clinical Neurological Sciences (A.B.), London Health Sciences Centre, Western University, Canada.

Go to Neurology.org/N for full disclosures. Funding information and disclosures deemed relevant by the authors, if any, are provided at the end of the article. 
significance. ${ }^{1}$ Both lacked spine lesions. Neither responded to symptomatic/immunosuppressive treatments. We hypothesize the perirolandic lesions caused Holmes tremor by disrupting nigrostriatal/cerebello-thalamocortical projections, although this requires confirmation. ${ }^{2}$ We suspect progressive multiple sclerosis (MS) as the etiology, given the striking similarity to prior reports of this presentation in $\mathrm{MS}^{3}$

\section{Study Funding}

No targeted funding reported.

\section{Disclosure}

A. Budhram, H.D. Simpson, and J.H. Bower report no disclosures relevant to the manuscript. A. Hassan is a site principal investigator for a clinical trial of N-acetyl-Lleucine on Niemann-Pick funded by Intrabio. B.L. Conway reports no disclosures relevant to the manuscript. E.P. Flanagan is a site principal investigator in a randomized placebo-controlled clinical trial of inebilizumab (a CD19 inhibitor) in neuromyelitis optica spectrum disorders funded by MedImmune/Viela Bio. He receives no personal compensation, just reimbursement for research activities related to the trial. Go to Neurology.org/ $\mathrm{N}$ for full disclosures.

\section{Publication History}

Received by Neurology July 17, 2020. Accepted in final form October 14, 2020.
Appendix Authors

\begin{tabular}{|c|c|c|}
\hline Name & Location & Contribution \\
\hline $\begin{array}{l}\text { Adrian } \\
\text { Budhram, } \\
\text { MD }\end{array}$ & $\begin{array}{l}\text { Mayo Clinic, } \\
\text { Rochester, MN }\end{array}$ & $\begin{array}{l}\text { Designed and conceptualized } \\
\text { study, drafted manuscript, } \\
\text { analyzed and interpreted the } \\
\text { data, composed the figure, } \\
\text { recorded the videos }\end{array}$ \\
\hline $\begin{array}{l}\text { Hugh D. } \\
\text { Simpson, } \\
\text { MBBS, PhD }\end{array}$ & $\begin{array}{l}\text { Mayo Clinic, } \\
\text { Rochester, MN }\end{array}$ & $\begin{array}{l}\text { Interpreted the data, revised } \\
\text { the manuscript for intellectual } \\
\text { content }\end{array}$ \\
\hline $\begin{array}{l}\text { James H. } \\
\text { Bower, MD }\end{array}$ & $\begin{array}{l}\text { Mayo Clinic, } \\
\text { Rochester, MN }\end{array}$ & $\begin{array}{l}\text { Interpreted the data, revised } \\
\text { the manuscript for intellectual } \\
\text { content }\end{array}$ \\
\hline $\begin{array}{l}\text { Anhar } \\
\text { Hassan, } \\
\text { MBBCh }\end{array}$ & $\begin{array}{l}\text { Mayo Clinic, } \\
\text { Rochester, MN }\end{array}$ & $\begin{array}{l}\text { Interpreted the data, revised } \\
\text { the manuscript for intellectual } \\
\text { content }\end{array}$ \\
\hline $\begin{array}{l}\text { Brittani L. } \\
\text { Conway, MD }\end{array}$ & $\begin{array}{l}\text { HealthPartners } \\
\text { Neuroscience Center, } \\
\text { St. Paul, MN }\end{array}$ & $\begin{array}{l}\text { Interpreted the data, revised } \\
\text { the manuscript for intellectual } \\
\text { content }\end{array}$ \\
\hline $\begin{array}{l}\text { Eoin P. } \\
\text { Flanagan, } \\
\text { MBBCh }\end{array}$ & $\begin{array}{l}\text { Mayo Clinic, } \\
\text { Rochester, MN }\end{array}$ & $\begin{array}{l}\text { Designed and conceptualized } \\
\text { study, analyzed and interpreted } \\
\text { the data, revised the } \\
\text { manuscript for intellectual } \\
\text { content, study supervision }\end{array}$ \\
\hline
\end{tabular}

\section{References}

1. Jarius S, Paul F, Aktas O, et al. MOG encephalomyelitis: international recommendations on diagnosis and antibody testing. J Neuroinflamm 2018;15:134.

2. Raina GB, Cersosimo MG, Folgar SS, et al. Holmes tremor: clinical description, lesion localization, and treatment in a series of 29 cases. Neurology 2016;86:931-938.

3. Karmon Y, Morrow SA, Weinstock A, Hojnacki D, Weinstock-Guttman B. Limb ataxia originating from peri-central sulcus demyelinating lesion in multiple sclerosis. J Neurol Sci 2012;320:136-140.

\section{Missed the Fall Conference? It's Now Available On Demand!}

Even if you missed the 2020 AAN Fall Conference, you can still access the quality CME, expert faculty, and innovative science at your convenience with Fall Conference On Demand! Access now at AAN.com/20FC.

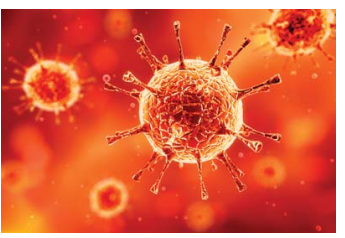

\section{COVID-19 and Neurologic Disease: Call for Papers!}

The editors of Neurology are interested in papers that address the neurological aspects of COVID-19 infection and challenges to the management of patients with chronic neurological conditions who have, or are at risk for, the infection. Relevant papers that pass initial internal review will undergo expedited peer review and online publication. We will consider papers posted in preprint servers.

Submit observational studies and clinical trials as Articles and case series and case reports under the Clinical/Scientific Notes category to https://submit.neurology.org/ today! 


\section{Neurology}

\section{Holmes Tremor With Perirolandic Demyelinating Lesions: A Distinct Clinicoradiographic Syndrome}

Adrian Budhram, Hugh D. Simpson, James H. Bower, et al.

Neurology 2021;96;231-232 Published Online before print November 20, 2020

DOI 10.1212/WNL.0000000000011235

This information is current as of November 20, 2020

\section{Updated Information \&} Services

References

Subspecialty Collections

Permissions \& Licensing

Reprints including high resolution figures, can be found at: http://n.neurology.org/content/96/5/231.full

This article cites 3 articles, 1 of which you can access for free at: http://n.neurology.org/content/96/5/231.full\#ref-list-1

This article, along with others on similar topics, appears in the following collection(s):

All Demyelinating disease (CNS)

http://n.neurology.org/cgi/collection/all_demyelinating_disease_cns MRI

http://n.neurology.org/cgi/collection/mri

Multiple sclerosis

http://n.neurology.org/cgi/collection/multiple_sclerosis

Tremor

http://n.neurology.org/cgi/collection/tremor

Information about reproducing this article in parts (figures,tables) or in its entirety can be found online at:

http://www.neurology.org/about/about_the_journal\#permissions

Information about ordering reprints can be found online:

http://n.neurology.org/subscribers/advertise

Neurology ${ }^{\circledR}$ is the official journal of the American Academy of Neurology. Published continuously since 1951, it is now a weekly with 48 issues per year. Copyright () 2020 American Academy of Neurology. All rights reserved. Print ISSN: 0028-3878. Online ISSN: 1526-632X.

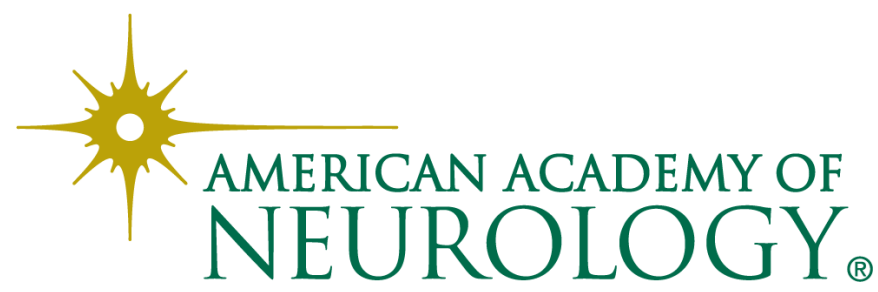

